\title{
Penerapan Model Evaluasi CIPP dalam Mengevaluasi Program Layanan PAUD Holistik Integratif
}

\author{
Lina Lina ${ }^{1 凶}$, Dadan Suryana ${ }^{2}$, Nurhafizah Nurhafizah ${ }^{3}$ \\ Pendidikan Anak Usia Dini, Universitas Negeri Padang
}

\begin{abstract}
Abstrak
Penelitian ini bertujuan untuk mengevaluasi program layanan Holistik Integratif dengan menggunakan analisis CIPP di Taman Kanak-Kanak Islam Khaira Ummah dengan menggunakan metode analisis model CIPP. Hasil penelitian diketahui bahwa TK Khaira Ummah telah menggunakan Kurikulum 2013, bekerjasama dengan dinas pendidikan, memiliki Standar Operasional Prosedur (SOP) pada tiap layanan, bekerjasama dengan puskesmas untuk layanan kesehatan dan penyediaan makan siang 4 sehat 5 sempurna bagi anak didik, serta larangan bagi anak didik membeli dan membawa jajanan dari luar.
\end{abstract}

Kata Kunci: holistik integratif; CIPP; taman kanak-kanak

\begin{abstract}
This study aims to evaluate Holistic Integrative service programs using CIPP analysis in Khaira Ummah Islamic Kindergarten using the CIPP model analysis method. The results of the study revealed that TK Khaira Ummah had used the 2013 Curriculum, in collaboration with the education office, had a Standard Operating Procedure (SOP) for each service, collaborated with health centers for health services, and provided 4 healthy 5 perfect meals for students, and prohibited students buy and bring snacks from outside..
\end{abstract}

Keywords: integrative holistic; CIPP; early childhood education

Copyright (c) 2019 Lina Lina, Dadan Suryana, Nurhafizah Nurhafizah

$\triangle$ Corresponding author :

Address : Padang, Sumatera Barat

ISSN 2356-1327 (Media Cetak)

Email : lina.new2017@gmail.com

ISSN $\underline{2549-8959}$ (Media Online) 


\section{PENDAHULUAN}

Lembaga Pendidikan anak usia dini dengan adanya Direktorat Pendidikan Non Formal dan Informal (PNFI) mengitegrasikan penyelenggaraan Taman Penitipan Anak (TPA), Kelompok Bermain (KB), Taman Kanak-Kanak (TK) dan Satuan Paud Sejenis (SPS).(Kemendikbud, 2014)

Perbedaan pendidikan formal dan non formal serta informal dalam penyelenggaraan Pendidikan Anak Usia Dini. Namun di lapangan terjadi perbedaan penafsiran dengan mendikotomikan antara Pendidikan Anak Usia Dini (PAUD) dengan TK menjadikan pengelolaan PAUD menjadi tidak menjunjung nilai Profesionalisme (Suryana, 2015)

PAUD Holistik Integratif (HI) adalah upaya pengembangan anak usia dini yang dilakukan untuk memenuhi kebutuhan esensial anak yang beragam dan saling terkait secara simultan, sistematis dan terintegrasi. Masyarakat berkonstribusi dalam pelaksanaan program pengembangan anak Holistik Integratif (HI), baik secara individu, kelompok, atau pun organisasi (Mushlih, Ahmad. Dkk, 2018).

Kompetensi pedagogik merupakan kemampuan guru dalam mengelola pembelajaran. kompetensi ini meliputi pemahaman tentang wawasan atau landasan kependidikan, pemahaman terhadap peserta didik, pengembangan kurikulum atau silabus, perancangan pembelajaran, pelaksanaan pembelajaran yang mendidik dan dialogis, pemanfaatan teknologi pembelajaran, evaluasi proses dan hasil belajar, serta pengembangan peserta didik untuk mengaktualisasikan berbagai potensi yang dimilikinya (Suryana, 2013)

Pengembangan pendidikan anak usia dini Holistik Integratif sudah direncanakan dan diterapkan secara sistematis di Satuan PAUD untuk mengoptimalkan potensi tumbuh kembang anak secara optimal agar kelak menjadi anak yang berkualitas dan berdaya saing di masa depan. Pengembangan Anak Usia Dini Holistik Integratif meliputi: pelayanan Gizi, pelayanan Kesehatan, pelayanan Pendidikan, pelayanan Pengasuhan, dan pelayanan perlindungan. (Syarbaini, 2016)

Layanan stimulasi holistik integratif mencangkup layanan pendidikan, kesehatan, gizi, perawatan, pengasuhan, perlindungan dan kesejahteraan menjadi kebijakan pengembangan anak usia dini dengan melibatkan pihak terkait baik instansi pemerintah, organisasi kemasyarakatan, organisasi profesi, tokoh masyarakat dan orang tua (Kemendikbud \& Indonesia, 2015). Dapat disimpulkan bahwa Pengembangan PAUD secara Holistik Integratif memang sangat penting dan harus menjadi tanggung jawab bersama. Karena itu keterlibatan semua pihak perlu dibangkitkan. Hal yang lebih penting adalah kesadaran bagi semua warga untuk memperhatikan tumbuh kembang peserta didik secara baik dan mampu mengembangkan potensi yang dimiliki anak secara optimal.

Beberapa anak akan menunjukkan karakteristik tertentu dan perilaku pada usia dini dari rekan-rekan mereka, akan mernakan waktu lebih lama untuk memperoleh keterarnpilan dan konsep anak. perkembangan anak akan itu adalah melalui pengamatan dekat dan interaksi dengan masing-masing anak dalarn kelas, mereka dapat di assesmen oleh guru setiap kemampuan yang mereka miliki, sehingga guru akan memberikan tindakan terhadap hasil penilaiannya untuk mengembangkan potensi yang dimiliki anak (Suryana, 2014)

Penelitian dari (Nurhafizah, 2011) menunjukkan bahwa setelah umur 8 tahun, tanpa melihat bentuk pendidikannya dan lingkungan yang diperoleh, kemampuan kecerdasan anak hanya dapat diubah 
348| Penerapan Model Evaluasi CIPP dalam Mengevaluasi Program Layanan PAUD

sebanyak 20\%. Dari hasil penelitian tersebut berarti bahwa selama usia 4 tahun pertama dari kehidupan anak dan dari usia 4-8 tahun kecerdasan anak sudah berkembang sebanyak $80 \%$. Hal ini menunjukkan betapa pesatnya pertumbuhan otak anak pada tahun-tahun tersebut. Demikian pesatnya dan pentingnya perkembangan yang terjadi pada masamasa awal kehidupan anak sehingga masa awal ini dikatakan sebagai masa emas (golden age). (Suryana, 2018) Masa ini hanya terjadi satu kali dalam kehidupan dan tidak dapat ditangguhkan pada periode berikutnya. Inilah yang menyebabkan masa anak sangat penting dalam kehidupan manusia. Karena itu, anak harus dipersiapkan dengan cara dibina dan dikembangkan agar berkembang optimal.

(Undang-Undang Nomor 23 Tahun 2003 Tentang Perlindungan Anak, 2003) tentang perlindungan anak pasal 9 ayat 1 , yang menyatakan bahwa "setiap anak berhak memperoleh pendidikan dan pengajaran dalam rangka pengembangan pribadinya dan tingkat kecerdasannya sesuai dengan minat dan bakat anak." Serta (Indonesia, 2003) Bab 1 Pasal 1 Butir 14, menyatakan bahwa "pendidikan anak anak usia dini adalah upaya pembinaan yang ditujukan kepada anak sejak lahir sampai dengan usia enam tahun yang dilakukan melalui rangsangan pendidikan untuk membantu pertumbuhan dan perkembangan jasmani dan rohani agar anak memiliki kesiapan dalam memasuki pendidikan lebih lanjut." Selanjutnya yang ketujuh adanya upaya pembinaan kepada sejak lahir hingga usia 6 tahun untuk membantu pertumbuhan dan perkembangan jasmani dan rohani agar anak memiliki kesiapan dalam memasuki pendidikan lebih lanjut (Nurhafizah, 2018). Anak mendapatkan kesempatan dalam proses pembelajaran yang ilmiah pada pembelajaran anak usia dini. Maka dari itu adanya dampak pada kemampuan berpikir anak dan wawasan anak saat anak menempuh pendidikan selanjutnya (Suryana, 2017).

Pemenuhan kebutuhan pendidikan anak usia dini Holistik Integratif adalah pemenuhan hak tumbuh kembang anak usia dini sebagai upaya peningkatan kesehatan, gizi, perawatan, pengasuhan, perlindungan, kesejahteraan dan rangsangan pendidikan yang dilakukan secara simultan, sistematis, menyeluruh, terintegrasi dan berkesinambungan (Peraturan Presiden RI Nomor 60 Tahun 2013 Tentang Holistik Integratif, 2013). Penyelenggaraan PAUD secara Holistik Integratif penting untuk kita pelajari karena adanya komunikasi yang baik antara orang tua dengan sekolah, orang tua satu dengan orang tua yang lainnya, dan dapat menambah wawasan, pengetahuan dan keterampilan orang tua dalam pendidikan anak, mengasuh dan mendidik anak (Laila, 2013).

Kunjungan awal yang dilakukan oleh peneliti pada hari Selasa, 07 Mei 2019 di TK Islam Khaira Ummah. Penulis melakukan wawancara tertutup kepada guru dan orang tua. Wawancara dari salah satu guru TK Islam Khaira Ummah menyatakan bahwa orang tua anak didik berpikir mengenai pendidikan atau pengasuhan anaknya sepenuhnya menjadi tanggung jawab orangtua atau keluarga, apabila orang tua anak bekerja dan tidak dapat mengasuh anaknya sendiri, orang tua lebih mempercayai pengasuh yang ada dirumahnya tanpa mengerti atau memperhatikan latar belakang pendidikan pengasuh. Namun, menurut guru bahwa pengasuhan anak wajib diterapkan di satuan PAUD, karena pengasuhnya berlatar belakang pendidikan yang jelas. Wawancara dari salah satu orang tua menyatakan bahwa kewajiban pengasuhan adalah tanggung jawab keluarga atau orang tua, dan guru disekolah berkewajiban untuk mengajarkan anak-anak mereka membaca, 
menulis dan berhitung. Agar anak mereka menjadi cerdas dan memiliki kesiapan untuk pendidikan selanjutnya. Guru juga memiliki peran penting terhadap kreativitas anak. Senada dengan pernyatan ini (Elena, 2013) menayatakan "An essential role, in this direction, is of the teachers, by identifying and stimulating the creative potential of the child.

Guru di TK Islam Khaira Ummah memberikan pendidikan untuk anak usia dini sesuai dengan tahap perkembangan anak. Artikel Petrus dan Felisitas yang berjudul "Penerapan Model evaluasi CIPP (Contect, Input, Product dan Process) mengevaluasi program layanan PAUD Holistik Integratif" yang bertujuan untuk merancang model evaluasi CIPP dalam mengevaluasi program layanan PAUD Holistik Integratif ditingkat satuan PAUD. Program layanan PAUD Holistik Integratif dari aspek Context, Input, Proses Dan Product, pada pengembangan objek dan evaluasi saja yang mengacu pada Perpres RI Nomor 60 Tahun 2013, tidak menyeluruh. Mengacu pada Perpres RI Nomor 60 Tahun 2013 (Jaya, Petrus Redy Partus. Ndeot, 2018).

Maka dari itu, peneliti ingin memberikan solusi tentang Holistik Integratif dengan judul: "Penerapan Model Evaluasi CIPP dalam Mengevaluasi Program Layanan PAUD Holistik Integratif. Penelitian (Jaya, Petrus Redy Partus. Ndeot, 2018) hanya memfokuskan objek dan evaluasi saja yang mengacu pada Perpres RI Nomor 60 Tahun 2013. Penulis merasa kurang kuat dan belum nampak untuk mengembangkan holistik integratifnya. Perpres No. 60 Tahun 2013 yang menjadi landasan yang kuat pada PAUD olistik Integratifi. Pengembangan PAUD Holistik Integratif harus dilaksanakan di satuan PAUD khususnya di TK Islam Khaira Ummah yang berada di kota Padang. Kewajiban untuk menyelenggarakan program pengembangan anak usia dini Holistik Integratif sesuai dengan amanah didalam Perpres No 60 Tahun 2013 secara menyeluruh.

Mengingatkan permasalahan diatas dapat kita pahami bahwa PAUD dalam pendidikan sangat penting untuk kita kaji, serta ada kemungkinan terjadinya hambatan dan kesalahan, jika dilaksanakan tanpa memperhatikan kaidah-kaidah dalam psikologi dan pendidikan. Pendidikan anak usia dini Holistik Integratif dapat dilihat dari sikap dan perilaku, kelompok, masyarakat, serta arah kebijakan instansi, lembaga baik swasta maupun pemerintah sesuai dengan kapasitas serta kewenangan masing-masing.

Keberhasilan suatu program tergantung dari bagaimana pengelola menyiapkan program tersebut tergantung dari bagaimana pengelola menyiapkan program tersebut dimulai dari perencanaan, pelaksanaan dan evaluasi yang akan dilaksanakan agar tujuan dari program tersebut dapat tercapai sesuai dengan harapan. Pendidikan Anak Usia Dini Holistik Intergratif yang menekankan adanya keterpaduan antara seluruh komponen yang mendukung keberhasilan tumbuh kembang anak menuntut seorang pengelola menjalin hubungan yang baik dengan seluruh komponen tersebut melalui kemitraan atau kerjasama dengan berbagai pihak yang terkait dalam pengembangan program PAUD Holistik Integratif. Bentuk layanan pendidikan anak usia dini yang terintegrasi dengan lembaga lain salah satunya adalah pos PAUD, yang berdiri dibawah naungan kelompok PKK sehingga dalam penyelenggaraannya terintegrasi dengan Posyandu, BKB (Bina Keluarga Balita) yang merupakan program dari Pembinaan Kelompok Keluarga (PKK), Puskesmas atau lembaga-lembaga lain yang terkait. 
Penelitiannya bertujuan mengevaluasi program layanan PAUD Holistik Integratif dengan menggunakan analisis CIPP di TK Islam Khaira Ummah, dalam menerapkan dan mengembangkan PAUD Holistik Integratif sesuai dengan kebutuhan anak didik dengan dasar landasan hukum Perpres Nomor 60 Tahun 2013.

\section{METODOLOGI}

Penelitian dilaksanakan di TK Islam Khaira Ummah Kota Padang. Provinsi Sumatra Barat. Objek penelitian adalah lembaga, guru dan orang tua anak didik. Metode yang digunakan adalah penelitian kualitatif dengan Model Evaluasi CIPP (Context, Input, Process Dan Product,). Teknik pengumpulan data dilakukan dengan observasi, wawancara dan dokumentasi. Alat observasi yang digunakan berbentuk catatan lapangan, wawancara dilakukan pada kepala sekolah dan orang tua anak didik. Data dokumentasi berupa foto sebagai lampiran untuk memperkuatkan hasil penelitian. Data dianalisis dengan menggunakan analisis model evaluasi $C I P P$.

\section{HASIL DAN PEMBAHASAN}

\section{Conteks Evaluation (Evaluasi Konteks)}

Evaluasi konteks adalah analisis kebutuhan (needs assesment). Pertanyaan utama dalam komponen ini adalah "apa yang dibutuhkan?”. Konteks penyelenggaraan PAUD Holistik Integratif, pertanyaan utama tersebut dapat dikembangkan menjadi "apa yang dibutuhkan oleh anak usia dini di TK Islam Khaira Ummah yang di evaluasi sesuai dengan isi Perpres No. 60 Tahun 2013?”.

Evaluasi konteks dalam hal ini bertujuan untuk mengetahui apakah penyelenggaraan program pengembangan anak usia dini di TK Islam Khaira Ummah memiliki landasan formal yang kuat serta apakah program pengembangan anak usia dini holistik integratif dinilai respon terhadap permasalahan yang ada di TK Islam Khaira Ummah. Yang menjadi landasan hukum yang kuat adalah Perpres No 60 2013. Maka, pengembangan PAUD Holistik Integratif harus dilaksanakan di satuan PAUD khususnya TK Islam Khaira Ummah yang berada di Kota Padang. Kewajiban untuk menyelenggarakan program pengembangan anak usia dini Holistik Integratif sesuai dengan amanah didalam Perpres No 60 Tahun 2013.

Berdasarkan hasil wawancara (Tanggal 14 Mei 2019) dengan ibu Rahma Erina Zur, S.Pt, kepala sekolah TK Islam Khaira Ummah, beliau menyatakan bahwa umumnya respon masyarakat khususnya orang tua anak didik kepada TK Islam Khaira Ummah adalah sebagai tempat belajar membaca, menghitung dan menulis, agar anak siap untuk melanjutkan pendidikan selanjutnya. Sehingga anak harus mampu membaca, menghitung dan menulis. Dan orang tua juga mengingikan anaknya berprestasi dibidang akademik setelah menempuh pendidikan di satuan PAUD, orang tua menginginkan anaknya cepat beradaptasi disekolah lanjutan, kemudian anaknya memiliki kemandirian dan disiplin, dan memiliki percaya diri yang tinggi.

Dengan banyaknya keinginan yang menuntut TK Islam Khaira Ummah oleh orang tua anak didik. orang tua selalu mendukung aktivitas yang dilaksanakan di TK. Salah satu point terpentingnya aktif melaksanakan kegiatan parenting. Sehingga memudahkan guru-guru untuk beradaptasi dengan anak dan orang tua anak dan ada kerjasamanya antara pihak TK dengan masyarakat khususnya orang tua anak didik.

Dari hasil wawancara diatas, sesuai dengan tuntunan masyarakat maupun orang tua, idealnya anak harus memiliki 
kesehatan yang baik, pengasuhan yang baik, keamanan yang memadai serta tingkat kesejahteraan yang baik. Sehingga untuk mendapatkan hasil yang maksimal, lembaga PAUD harus menyelenggarakan layanan pengembangan PAUD Holistik Integratif diperlukan dukungan dari masyarakat dan orang tua anak didik untuk menjadikan lembaga PAUD sebagai layanan yang mampu untuk memenuhi kebutuhan anak.

\section{Input Evaluation (Evaluasi Masukan)}

Komponen evaluasi masukan memusatkan perhatian pada rencana dan strategi yang harus dilakukan. Pertanyaan utamanya adalah: "apa yang harus dilakukan (what should be done)?" rencana apa yang harus dilakukan oleh satuan PAUD?; lembaga atau instansi apa saja yang terkait dengan satuan PAUD?; bagaimana koordinasi dan kerjasama satuan PAUD dengan instansi terkait?; bagaimana program kerja dan Standar Operational Procedure (SOP) penyelenggaraan PAUD Holistik Integratif di satuan PAUD?; bagaimana kompetensi tenaga pendidik satuan PAUD?; bagaimana ketersediaan sarana dan prasarana pendukung? Dan, sumber dana/standar pembiayaan?. Setiap pertanyaan ini dapat dikembangkan oleh evaluator.

Hasil wawancara (Tanggal $14 \mathrm{Mei}$ 2019) dengan ibu Rahma Erina Zur, S.Pt, kepala sekolah TK Islam Khaira Ummah, menyatakan bahwa TK Islam Khairah Ummah memiliki kerja sama dengan Puskesmas Tabing Kota Padang. Kerjasama tersebut bersifat tertulis adanya kesepakatan antara pihak PAUD dengan Puskesmas. Untuk mendapatkan akses layanan kesehatan dan gizi pada anak. Kunjungan Puskesmas ke TK Islam Khaira Ummah sudah memiliki jadwal yaitu 2 (Dua) kali kunjungan dalam 1 (Satu) Semester. Berarti dalam 1 Tahun, 2 (Dua) Semester ada 4
(Empat) kali kunjungan. Dalam kunjungan tersebut penerapan kesehatan ke anak TK Islam Khaira Ummah melalui Pemberian Vit A, periksa gigi, pencatatan deteksi dini tumbuh kembang anak, menukur berat badan dan tinggi badan anak. Dan kerja sama kunjungan oleh Puskesmas sudah berjalan sekitar 4 tahun.

Penerapan gizi pada anak, TK Islam Khaira Ummah mamiliki peraturan yang dibuat antara pihak kepala sekolah dan guru. Untuk jadwal makan siang disiapkan oleh pihak sekolah dengan menu bergantian setiap harinya, seperti nasi, lauk pauk, sayur mayur, minum, bubur kacang hijau dan khusus untuk hari kamis disediakan buahbuahan. Apabila masih dilingkungan sekolah, anak-anak dilarang jajan atau membawa jajan dari rumah. Kecuali diluar kegiatan sekolah.

Sarana prasarana serta sumber daya sesungguhnya tidak menjadi kendala dalam penyelenggaraan program Pengembangan PAUD Holistik Integratif di satuan PAUD. Untuk sarana kegiatan penyelengaraan program seperti kegiatan parenting, penyuluhan kesehatan, dan lain sebagainya dapat memakai ruang kelas pada tiap-tiap lembaga satuan PAUD. Maka pengembangan PAUD Holistik Integratif di TK Khaira Ummah terlaksana dengan baik (Hasil Wawancara Pada Tanggal 14 Mei 2019).

Dari hasil wawancara diatas dapat saya simpulkan bahwa untuk penyelenggaraan layanan kesehatan dan gizi di TK Islam Khaira Ummah tidak membutuhkan sarana prasarana yang sulit untuk disiapkan. TK Islam Khaira Ummah hanya perlu menyediakan tempat yang bisa digunakan untuk melaksanakan kegiatankegiatan yang berkaitan dengan layanan kesehatan dan gizi.

Pada pengasuhan dan keamanan belum berjalan sesuai dengan Perpres No 60 Tahun 2013. Karena hasil wawancara 
dengan kepala sekolah TK Islam Khaira Ummah menyatakan bahwa belum ada koordinasi antara TK Islam Khaira Ummah dengan kepolisisan. Namun, pengasuhan dari pihak sekolah dilaksanakan melalui mulai menyambut anak datang di PAUD, sampai guru mengantarkan anak yang dijemput orang tuanya sampai dipagar. Pengasuhan yang dilakukan pihak PAUD berdasarkan SOP (Standar Operasional Prosedur). Dan keamanan dari pihak PAUD adalah mengantisipasi bahwa lokasi TK berada dipinggir jalan, untuk keamanan anak disediakan Penjaga PAUD, pagar yang tinggi, tempat bermain dipagar dan dikunci.

Kesimpulannya bahwa hanya layanan kesehatan melalui koordinasi antara Puskesmas dan TK Islam Khaira Ummah yang sudah berjalan dan untuk sumber daya yang lain seperti sumber daya keamanan dan pengasuhan juga dinilai memadai dalam perspektif asumsi peneliti dari TK
Islam Khaira Ummah. Kemanan dan pengasuhan dilakukan hanya antara kepala sekolah, guru, penjaga TK Islam Khaira Ummah dan orang tua.

\section{Process Evaluation (Evaluasi Proses)}

Evaluasi proses adalah pelaksanaan program. Pertanyaan kuncinya: "apakah program sedang dilaksanakan (it is being done)?". Program layanan PAUD Holistik Integratif terdiri dari 5 jenis layanan, yaitu: (1) layanan pendidikan; (2) layanan pengasuhan, (3) layanan keamanan; (4) layanan kesehatan; dan (5) layanan gizi. Objek evaluasi komponen proses adalah memastikan keterlaksanaan berbagai program layanan yang telah disebutkan berdasarkan skala prioritas yang telah ditentukan. Selain itu, objek evaluasi juga dapat berkaitan dengan model penyelenggaraan PAUD Holistik Integratif baik yang terpadu maupun terpisah.

Tabel 1. Hasil Wawancara

\begin{tabular}{|c|c|c|}
\hline No & $\begin{array}{c}\text { Layanan } \\
\text { PAUD HI } \\
\end{array}$ & Wawancara \\
\hline 1 & Pendidikan & $\begin{array}{l}\text { - Menggunakan Kurikulum } 13 \\
\text { - Bekerjasama dengan dinas pendidikan } \\
\text { - Pembelajaran sesuai dengan tahap perkembangan anak } \\
\text { - Harapan orang tua anak harus mampu membaca, menghitung dan menulis. } \\
\end{array}$ \\
\hline 2 & Pengasuhan & $\begin{array}{l}\text { - PAUD memiliki SOP } \\
\text { - Adanya daftar piket guru untuk menyambut kedatangan anak didik ke satuan PAUD } \\
\text { - Waktu pulang Guru kelas menjaga anak didik didalam kelas sampai anak didik di } \\
\text { - jemput. } \\
\text { - Guru kelas wajib mengantarkan anak didik pulang sampai depan pagar. }\end{array}$ \\
\hline 3 & Keamanan & $\begin{array}{l}\text { - Belum ada mendapatkan kunjungan kerjasama antara PAUD dengan kepolisian } \\
\text { - PAUD mempunyai penjaga di lembaga } \\
\text { - Pagar yang tinggi dan tempat bermain terjaga keamanannya }\end{array}$ \\
\hline 4 & Kesehatan & $\begin{array}{l}\text { - PAUD memiliki buku riwayat kesehatan } \\
\text { - Adanya kerjasama pihak PAUD dengan puskesmas } \\
\text { - Akses layanan berupa periksa gigi, pemberian Vit A, pencatatam deteksi dini tumbuh } \\
\text { kembang anak dan mencatat tinggi dan berat badan anak. }\end{array}$ \\
\hline 5 & Gizi & $\begin{array}{l}\text { - PAUD menyediakan makan siang } 4 \text { sehat } 5 \text { sempurna } \\
\text { - PAUD memiliki buku pedoman tentang kesehatan dan gizi anak. } \\
\text { - Dilarang membeli jajan dan membawa jajan saat kegiatan dan di kawasan PAUD. }\end{array}$ \\
\hline
\end{tabular}

Dari tabel diketahui bahwa hasil evaluasi proses program pengembangan anak usia dini Holistik Integratif di TK Islam Khaira Ummah bahwa koordinasi dengan instansi terkait pelayanan pengembangan anak usia dini Holistik Integratif termasuk dalam katagori baik. Karena dari layanan pendidikan adanya 
kerjasama PAUD dengan Dinas Pendidikan Kota Padang dalam melakukan bimbingan teknis, pelatihan serta evaluasi terkait penyelenggaraan program pendidikan di TK islam khaira ummah dengan optimal. Layanan kesehatan adanya kerjasama pihak PAUD dengan Puskesmas termasuk katagori tinggi, atau telah berjalan dengan baik. Hal ini menandakan bahwa layanan kesehatan telah dijalankan oleh Dinas Kesehatan melalui Puskesmas setempat.

Peran kepolisian dalam layanan keamanan dalam pelaksanaan layanan Pengembangan Anak Usia Dini Holistik Integratif di TK Islam Khaira Ummah dalam kategori rendah, atau belum adanya koordinasi dengan baik antara TK Islam Khaira Ummah dengan pihak kepolisisan. Namun, kerjasama dengan tokoh masyarakat setempat guna meningkatkan penyelenggaraan layanan PAUD.

Kemudian peran orang tua sebagai mitra termasuk dalam dalam kategori baik. Dengan demikian, dari seluruh unsur yang terkait hanya layanan kesehatan dan gizi serta peran orang tua yang sudah berjalan dengan baik.

\section{Product Evaluation (Evaluasi Produk)}

Komponen terakhir dalam model evaluasi CIPP adalah komponen evaluasi produk. Titik tolak evaluasi pada komponen ini terletak pada pertanyaan: "apakah program sukses (Did it success)?”. Apakah program layanan PAUD Holistik Integratif telah berhasil?" berapakah tingkat keberhasilan penyelenggaraan PAUD Holistik Integratif di satuan PAUD?". Ini adalah sejumlah pertanyaan yang menjadi focus kajian evaluasi komponen produk. Selanjutnya pengembangan pertanyaan evaluasi menacu pada indikator keberhasilan tiap layanan PAUD Holistik Integratif yang termuat dalam juknis penyelenggaraan PAUD Holistik Integratif.
Hasil wawancara (Tanggal 14 Mei 2019) dengan ibu Rahma Erina Zur, S.Pt, kepala sekolah TK Islam Khaira Ummah menyatakan bahwa, layanan kesehatan yag diberikan oleh Puskesmas di TK Islam Khaira Ummah sangat membantu orang tua untuk mengetahui perkembangan kesehatan dan gizi anaknya, dan membantu orang tua memberikan makanan yang bergizi bagi anak, serta batasan-batasannya. Layanan ini juga membantu pihak sekolah dalam penilaian hasil perkembangan kesehatan dan gizi anak didiknya. Beberapa orang tua anak didik menyampaikan kepada guruguru bahwa anak mereka tidak hanya mendapatkan layanan kesehatan, akan tetapi juga mendapatkan layanan pendidikan, layanan pengasuhan yang sangat menguntungkan orang tua.

TK Islam Khaira Ummah berupaya menanamkan pengetahuan kepada orang tua anak akan pentingnya pemenuhan aspek kesehatan dan gizi anak. Menepis anggapan bahwa bahwa layanan kesehatan dan gizi, dinilai tidak terlalu penting dilaksanakan di satuan PAUD.

Layanan yang dilaksanakan oleh Puskesmas di TK Islam Khaira Ummah adalah menanamkan kesadaran terhadap pentingnya kesehatan anak dan dilakukan bersama-sama. Dari hasil analisa penulis, ditemukan hubungan kemitraan antara TK Islam Khaira Ummah dengan orang tua anak dalam memantau pertumbuhan dan perkembangan anak. Kemitraan tersebut dapat menjadi pondasi yang kuat bagi satuan PAUD untuk melaksanakan pelayanan dengan maksimal, mengacu pada tujuan layanan PAUD Holistik Integratif yaitu kesiapan anak usia dini baik kesiapan mental, spiritual, sosial serta intelektual dalam melaksanakan kegiatan pendidikan yang akan ditempuhnya kelak, serta dapat menjadi generasi penerus bangsa yang dapat bersaing di era global. 
354| Penerapan Model Evaluasi CIPP dalam Mengevaluasi Program Layanan PAUD

Penyelenggaraan program PAUD Holistik Integratif memiliki landasan hukum Perpres No. 60 Tahun 2013 tentang Holistik Integratif. TK Islam Khaira Ummah telah menggunakan Kurikulum 2013, pembelajaran telah sesuai dengan tahap perkembangan anak dan harapan orang tua, telah memiliki SOP, untuk piket guru, menyambut kedatangan dan kepulangan anak didik. memiliki buku riwayat kesehatan anak, kerjasama dengan puskesmas, dan menyediakan makan siang 4 sehat 5 sempurna dan anak dilarang membeli dan membawa jajanan di kawasan sekolah.

\section{UCAPAN TERIMA KASIH}

Terima kasih terutama kepada bapak Dr. Dadan Suryana, M.Pd atas bimbingan dan dukungan kepada penulis. Ibu Nurhafizah, M.Pd atas masukan kepada penulis, dan editor dan reviewer Jurnal Obsesi : Jurnal Pendidikan Anak Usia Dini yang telah memberikan masukan dalam penulisan artikel ini.

\section{DAFTAR PUSTAKA}

Elena, D. (2013). The Determinsm for Attitude Factors in Pre-school Children for Amplifying His Creative Manifestations. Procedia -Social and Behavioral Sciences, 76, 291-296. https://doi.org/10.1016/j.sbspro.2013. 04.115

Indonesia, R. (2003). Undang-Undang Nomor 20 Tahun 2003 Sistem Pendidikan Nasional. Jakarta.

Jaya, Petrus Redy Partus. Ndeot, F. (2018). Penerapan Model Evaluasi CIPP Dalam Mengevaluasi Program Layanan PAUD Holistik Integratif. PERNIK Jurnal PAUD, $1,1$.

Kemendikbud, \& Indonesia, R. (2015). Petunjuk Teknis Penyelenggaraan PAUD Holistik Integratif di Satuan
PAUD [Technical Guide on the Implementation of Holistic Intergative ECD in ECE Units].

Kemendikbud, R. I. (2014). Permendikbud Nomor 137 Tahun 2014 Tentang Standar Nasional Pendidikan Anak Usia Dini.

Laila, L. . (2013). Penyelenggaraan Program PAUD Holistik Integratif di PAUD Siwi Kencana Kota Semarang. Journal of Non Formal Education, 2, 73-82.

Mushlih,Ahmad.

Rahimah.

Insiyah,Ma'fiyatun. Muzdalifah. Uminar, Ajeng Ninda. Imami, Fidzah. Maula, Inayatul. Parapat, Asmidar. Lestari, Puti. Khairunnisa, Lina. Rahmawati, Yuning Eka. Maisari, Sri. Munafiah, Nida'ul. Wathani, Septia Nrul. Rahimah. Susanti, H. (2018). Analisis Kebijakan PAUD: Mengungkap Isu-isu Menarik Seputar AUD. Jakarta.

Nurhafizah, N. (2011). Kemampuan Berkomunikasi Sebagai Pilar Profesional Guru Dalam Membimbing Anak Usia Dini. Artikel Proseding. Bandung: FIP UPI.

Nurhafizah, N. (2018). Pelatihan Pembuatan Media Pembelajaran Anak Usia Dini Menggunakan Bahan Sisa. Jurnal Pendidikan: Early Childhood, 2(2), 1-10.

Peraturan Presiden RI Nomor 60 Tahun 2013 Tentang Holistik Integratif. (2013). Jakarta.

Suryana, D. (2013). Pengetahuan Tentang Strategi Pembelajaran, Sikap dan motivasi Guru. (January 2013). https://doi.org/10.17977/jip.v19i2.421 2

Suryana, D. (2014). Kurikulum Pendldikan Anak Usia Dini Berbabasis Perkembangan Anak. Pesona Dasar, 1 No.3.

Suryana, D. (2015). Profesionalisme Guru 
Pendidikan Anak Usia Dini Berbasis Peratura Menteri No. 58 Tahun 2009. PEDAGOGI | Jurnal Ilmiah Ilmu Pendidikan Volume: XV No.2., XIII(2), 118-124.

Suryana, D. (2017). Pembelajaran Tematik Terpadu Berbasis Universitas Negeri Padang Harus dapat Memberikan Kesempatan Umum. 6, 67-82.

Suryana, D. (2018). Efektifitas Mencetak Percikan Daun Terhadap Perkembangan Motorik Halus Anak Di Taman Kanak-kanak Aisyiyah Suayan. Jurnal Usia Dini, 4 no. 2(2), 55-66.

Syarbaini, E. R. (2016). Early Childhood Anti-Violence Education in The Perspective of Psychology. Indonesian Journal of Islamic Early Childhood Education, 1(1), 91-100.

Undang-Undang Nomor 23 Tahun 2003 Tentang Perlindungan Anak. (2003). jakarta. 